\title{
MORPHO-NUTRITIONAL RESPONSE OF LETTUCE (LACTUCA SATIVA L.) TO ORGANIC WASTE EXTRACTS GROWN UNDER HYDROPONIC CONDITION
}

\author{
ARSHAD, M..$^{{ }^{*}}$ - NAWAZ, R. ${ }^{2}-$ AHMAD, S. ${ }^{3}-$ QAYYUM, M. M. N. ${ }^{1}-$ ALI, Z. ${ }^{1}-$ FAIZ, F. ${ }^{1}-$ \\ MANZOOR, H. M. I. ${ }^{1}$ \\ ${ }^{I}$ Department of Agriculture \& Food Technology, Karakoram International University \\ 15100 Gilgit, Pakistan \\ (e-mails:dr.arshad@kiu.edu.pk,mir.qayyum@kiu.edu.pk,zulfiqar.ali@kiu.edu.pk, \\ furrukhfaiz@kiu.edu.pk,muhammad.irfan@kiu.edu.pk) \\ ${ }^{2}$ Department of Environmental Sciences, The University of Lahore, Pakistan \\ (e-mail:rnuaf@yahoo.com)
}

${ }^{3}$ Department of Environmental Sciences, COMSATS Institute of Information Technology (CIIT), Vehari Campus, Pakistan

(e-mail: sajjadahmadjoya@gmail.com)

*Corresponding author

e-mail: arshad4humanity@yahoo.com,dr.arshad@kiu.edu.pk; phone:+92-301-690-7730

(Received 24 $4^{\text {th }}$ Feb 2018; accepted $21^{\text {st }}$ May 2018)

\begin{abstract}
Organic wastes are utilized as source of nutrients to grow vegetables and reduce environmental degradation. This research aimed to study influence of different concentrations of organic waste extracts (Goat Manure Extract, GME; Banana Peel Extract, BPE) as $\mathrm{T}_{0}: 0 \%$ GME and BPE (control: irrigation water), $\mathrm{T}_{1}: 1 \% \mathrm{GME}, \mathrm{T}_{2}: 2 \% \mathrm{GME}, \mathrm{T}_{3}: 3 \% \mathrm{GME}, \mathrm{T}_{4}: 3 \% \mathrm{GME}+1 \% \mathrm{BPE}, \mathrm{T}_{5}: 3 \% \mathrm{GME}+2 \% \mathrm{BPE}$ on morphological and nutritional traits of loose-leaf Lettuce through hydroponic experiment at Gilgit city in Pakistan. The number of leaves, fresh weight, dry weight, carbohydrates, fat, fiber, calcium, phosphorus, sodium, potassium, chromium, thiamine, niacin, and energy were higher by $74,7,72,13,157,100,6,15$, $9,4,33,150,68,53$ and $52 \%$, respectively, under $\mathrm{T}_{5}$, whereas protein, ash, iron and riboflavin were greater by $86,200,105$ and $292 \%$, respectively, under $\mathrm{T}_{4}$ compared to $\mathrm{T}_{\mathrm{o}}$ treatment except moisture contents. Number of leaves, leaf fresh weight, leaf dry weight, and leaf moisture are strongly related to and are good predictors $\left(\mathrm{R}^{2}=0.67-0.97\right)$ of energy production from Lettuce. Integrated utilization of organic waste extracts $\left(T_{4}-T_{5}\right)$ increased Lettuce leaf yield components and its nutritional value for human consumption.
\end{abstract}

Keywords: banana peel, goat manure, minerals, nutrients, organic extracts, vitamins

\section{Introduction}

Organic hydroponic production of leafy vegetables under controlled environment is one of the most appropriate technologies to accomplish human food requirements in soilless mountainous and urban areas. This production technology is economically viable to curb food insecurity in urban and rural hardship locations (Croft et al., 2017). Organic productions are preferred owing to inherent health benefits and lack of side effects for human body. Agricultural wastes (farmyard and fruits) are abundantly produced worldwide. Improper management and utilization of these wastes result in environmental degradation and the spreading of diseases (Manahan, 2005). These organic wastes especially manures and fruit peels (banana) serve as potential sources of macro- and micronutrients for crop production (Golabi et al., 2004; Kowalska et al., 2017). Under conventional soil based methods of vegetable production, success of accepted organic 
fertilizer component is dependent on soil decomposer which convert these wastes into useable form of nutrients which are absorbed by plants (Clark et al., 1998). Hydroponic production technology provides an opportunity to grow diverse type of leafy and fruity vegetables using organic sources of plant nutrients (El-Kazzaz and El-Kazzaz, 2017).

Leafy vegetable like Lettuce (Lactuca sativa L.) is an annual crop having fibrous root system that survives under diverse temperature situations (Manolopoulou and Varzakas, 2016) and respond to nitrogen levels positively (Gonzalez et al., 2016). It is a rich source of nutrients, minerals and vitamins for human body (Roy and Chakrabarti, 2003; Orech et al., 2007). The vegetable is being grown hydroponically in greenhouses using both salt based fertilizers and organic extracts (Rosik-Dulewska and Grabda, 2002). Though, greenhouse vegetable production is an intensive system mainly used in commercial farming (Kittas et al., 2013). This cultivation is achieved through modifying nutrient medium to optimum levels through testing and comparing different manure extracts. In hydroponics, nutrients which are required for plant growth are provided directly while eliminating needs for soil and soil organisms completely. Direct nutrition results have been noted in the form of higher growth rates and yields compared to soil cultivation (Raviv and Lieth, 2008). But consumers want to buy produce which is not tainted with hazardous chemicals or poisons as result of inorganic methods of nutrition.

Merits and demerits are associated with both organic and salt-based fertilizers. In saltbased fertilizers, nutrient concentration per unit weight is higher, availability is uniform and immediate, and precision of nutrient analysis is rapid compared to organic fertilizer. Mineral nitrogen is productive three-fold more than an organic nitrogen source (Masclaux-Daubresse et al., 2010). Yields were not different for a range of vegetables produced with organic $\mathrm{N}$ fertilizers compared to inorganic $\mathrm{N}$ fertilizers (Fabio et al., 2007). Gradual diminishing resources of world shows concerns about disadvantages of salt-based fertilizers. This includes excessive energy needs for formation, pollution due to mining and processing, and potential dwindling of finite resources of phosphorous and potassium (Fischer, 1986). The main disadvantage to salt-based fertilizers is that these are synthetically prepared which means the composition of material is chemically or genetically changed by combining, extracting or refining through human activity. Comparatively, organic fertilizers derived from animal or plant wastes are utilizable and recyclable (Elamin and Elagib, 2001). Moreover, organic produce has greater sale price compared to conventional produce (Sgroi et al., 2015). The nutritional value of organic foods compared to traditional ones is twofold the elemental composition on fresh weight basis (Matt et al., 2011; Orman and Kaplan, 2017). Hence the objective of this research was to explore and evaluate prospect of utilization of organic wastes of banana peel and goat manure as source of nutrients for hydroponic production of loose leaf Lettuce vegetable in food insecure soilless mountainous and urban areas.

\section{Material and methods}

\section{Experimental site and layout}

Research was conducted from March 25 to June 10, 2016 inside a greenhouse (GH) of $16 \mathrm{ft}$ width (bottom), $8 \mathrm{ft}$ height and $40 \mathrm{ft}$ length located at Karakoram International University, Gilgit, Pakistan, having coordinates of 35.91 Latitude and 74.31 Longitude (Fig. 1). Temperature remained inside $\mathrm{GH}$ was between 20 and $30{ }^{\circ} \mathrm{C}$ and was greater by a few degrees compared to outside. Average relative humanity was remained around $65 \%$. Inside GH structure, eighteen sets each made of PVC pipe (3 ft) fitted on an iron 
stand and were arranged to accommodate six treatments with three replications. Within each set, pipe was connected with water inflow pipe and a drainage pipe using connection pipes. Each pipe is closed on both ends with cups and had inlet on one end and an outlet on the other end. Each treatment set was connected with main pipes for supply of water at top and with a drainage pipe at bottom. Main water supply pipe was connected to water storage tank where water supply was controlled with a valve, while drainage pipe served as an outlet from the GH. Each small piece of pipe within a treatment set had five holes to accommodate a gutter containing growth medium (perlite) to anchor a Lettuce plant. Water flow from the tank was maintained to each set (treatment) at the rate of $0.5 \mathrm{~L}$ per minute (Fig. 2).
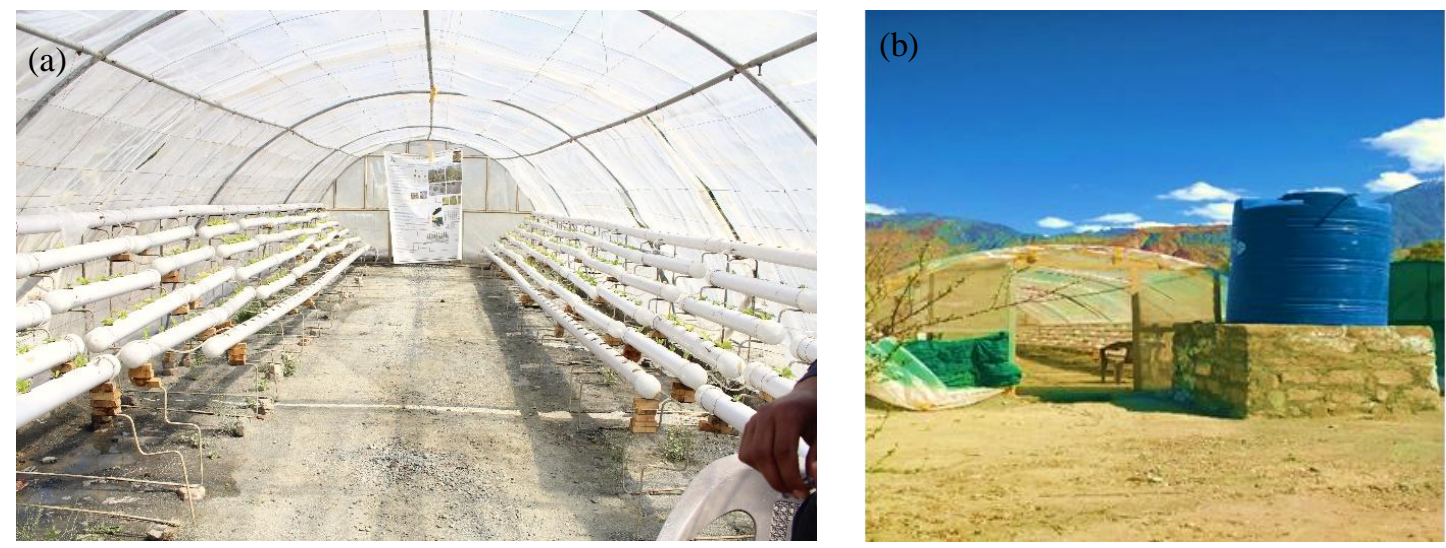

Figure 1. Experimental site ( $a$ : inside; $b$ : outside) for hydroponic production of loose leaf lettuce under greenhouse condition

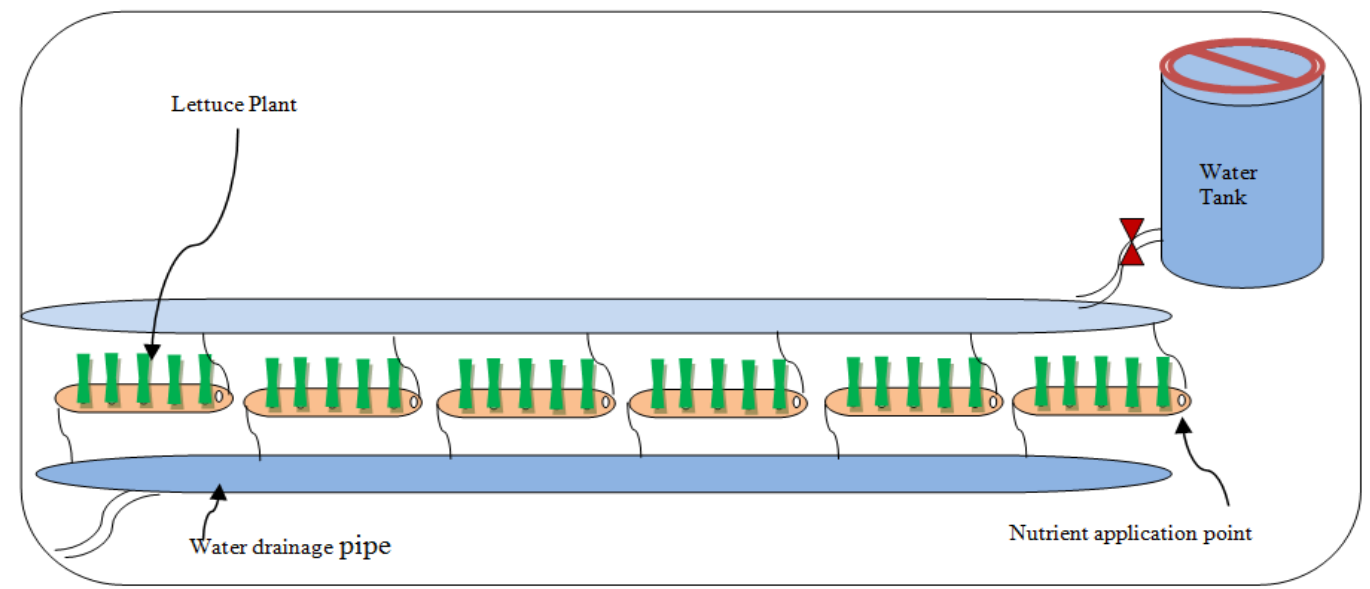

Figure 2. Schematic diagram of hydroponic system for lettuce production

\section{Pre-experiment nutrient solution preparation}

Two types of extracts were prepared one from goat manure (GM) and the second from Banana peel (BP). Banana peel of fully matured fruit (yellow colored with black spots) was procured from market and goat manure was obtained from a goat farmer in composted condition. Five kilograms of each organic material was boiled into $20 \mathrm{~L}$ of 
water in a container over a gas stove till a concentrated solution of $5 \mathrm{~L}$ after filtration was obtained.

\section{Experimental organization and management}

Experimental plant loose-leaf Lettuce (Lactuca sativa var. crispa) of family Asteraceae was seeded in five pots placed in five holes of a pipe of $3 \mathrm{ft}$ long. Six concentrations prepared from concentrated extracts of GM and BP $\left(\mathrm{T}_{\mathrm{o}}: 0 \% \mathrm{GME} / \mathrm{BPE}\right.$, $\mathrm{T}_{1}: 1 \% \mathrm{GME}, \mathrm{T}_{2}: 2 \% \mathrm{GME}, \mathrm{T}_{3}: 3 \% \mathrm{GME}, \mathrm{T}_{4}: 3 \% \mathrm{GME}+1 \% \mathrm{BPE}, \mathrm{T}_{5}: 3 \% \mathrm{GME}+2 \%$ $\mathrm{BPE}$ ) in total volume of $0.5 \mathrm{~L}$. These treatments/ concentrations were assigned to eighteen sets randomly on the basis of CRD statistical design. The nutrient formulations (diluted) were applied to assigned treatment sets on alternate days. Treatment concentrations were analyzed for major and some minor plant nutrients i.e., Nitrogen, Phosphorus, Potassium, Calcium, Sodium, Chromium, Iron, pH, and EC using standard methods (Table 1).

Table 1. Nutrient analysis of treatment solutions prepared from organic extracts

\begin{tabular}{|c|c|c|c|c|c|c|}
\hline \multirow[b]{2}{*}{ Nutrient } & \multicolumn{6}{|c|}{ Plant nutrition treatment } \\
\hline & $\begin{array}{c}\mathbf{T}_{\mathbf{o}}: \\
\text { Irrigation water } \\
(\mathbf{0 \%} \text { GME/BPE })^{*}\end{array}$ & $\begin{array}{c}\mathrm{T}_{1}: \\
1 \% \text { GME }\end{array}$ & $\begin{array}{c}T_{2}: \\
2 \% \text { GME }\end{array}$ & $\begin{array}{c}\text { T }_{3}: \\
\text { 3\% GME }\end{array}$ & $\begin{array}{c}\mathrm{T}_{4}: \\
3 \% \mathrm{GME}+ \\
1 \% \mathrm{BPE}\end{array}$ & $\begin{array}{c}\mathrm{T}_{5}: \\
3 \% \text { GME + } \\
2 \% \text { BPE }\end{array}$ \\
\hline Nitrates $(\mathrm{N}), \mathrm{mgL}^{-1}$ & 1.5 & 1.6 & 1.7 & 2.0 & 2.1 & 2.2 \\
\hline Phosphorus (P), mgL ${ }^{-1}$ & 0.001 & 0.003 & 0.005 & 0.006 & 0.008 & 0.010 \\
\hline Potassium $(\mathrm{K}), \mathrm{mgL}^{-1}$ & 2.0 & 2.5 & 2.8 & 2.9 & 3.1 & 3.2 \\
\hline Calcium $(\mathrm{Ca}), \mathrm{mgL}^{-1}$ & 58 & 62 & 66 & 72 & 76 & 80 \\
\hline Sodium $(\mathrm{Na}), \mathrm{mgL}^{-1}$ & 26 & 55 & 69 & 80 & 98 & 115 \\
\hline Chromium (Cr), $\mathrm{mgL}^{-1}$ & 0.01 & 0.02 & 0.02 & 0.03 & 0.04 & 0.05 \\
\hline Iron $(\mathrm{Fe}), \mathrm{mgL}^{-1}$ & 0.1 & 0.5 & 0.6 & 0.8 & 2.0 & 2.6 \\
\hline $\mathrm{pH}$ & 5.3 & 5.6 & 5.8 & 6.2 & 6.4 & 6.5 \\
\hline $\mathrm{EC}, \mathrm{dSm}^{-1}$ & 0.6 & 1.5 & 2.6 & 3.4 & 4.2 & 5.2 \\
\hline
\end{tabular}

*GME_goat manure extract; BPE_banana peel extract

\section{Morpho-nutritional measurement and analysis}

After sixty-five days of seeding, leaves of three plants of Lettuce were harvested from each replicate leaving behind the root portion. Number of leaves was counted and fresh weight of leaves was taken. Thereafter, harvested leaves were kept in an oven to dry at $105{ }^{\circ} \mathrm{C}$ till constant weight. Dry weight of the leaves was measured using an electronic balance and moisture contents were computed. The dried samples from each replicate were ground and sieved. Powdered triplicate samples were analyzed for proximate and mineral composition for nutritional evaluation of food material in accordance with AOAC (2000). Further, the samples were examined for vitamins, i.e., Thiamin, Riboflavin, Niacin, and Ascorbic acid. Thiamine and riboflavin were found by quantitative analysis as described by Hucker et al. (2011), Niacin was investigated by colorimetric method (Kawila, 2011) and Ascorbic acid (Vitamin C) was found through dichlorophenol Indophenol dye reduction method (Smirnoff, 2000). Kjeldhal method was adopted to find crude protein through determining nitrogen contents of food material. Sohxtech was used to determine crude fat through ether extraction process 
(Thiex et al., 2003). Crude fiber contents were found by acid digestion, alkali digestion and fibertech (Busuttil-Griffin et al., 2015). Ashing of samples was performed in a muffle furnace at $550{ }^{\circ} \mathrm{C}$ for 6 hours. For all these determinations powdered and oven dried samples were used in triplicate. Food energy of protein and carbohydrates was derived by multiplying with 4.1 and energy from fat was computed by multiplying with 9.3 (Khalil and Saleemullah, 2004; Arshad and Ranamukhaarachchi, 2012). Analysis of macro-minerals i.e., calcium, phosphorus, potassium, and sodium was carried by digestion of samples with $\mathrm{HClO}_{4}$ and $\mathrm{HNO}_{3}$ as proposed by Khattak and Rahman (2016) whereas for micro-minerals i.e., chromium and iron, dry ash method was adopted for digestion as described by Abbruzzini et al. (2014). Following the digestion, samples were analyzed for selected minerals using U.V. Spectrophotometer (ORION), Atomic Absorption Spectrometer (VARIAN) and Flame Photometer (SHER WOOD).

\section{Statistical analysis}

Data pertaining to number of leaves, leaf fresh weight, leaf dry weight, nutritional composition, mineral contents and vitamins were analyzed using statistical program SAS version 9.0 for one-way Analysis of Variance (ANOVA) and Fisher protected Least Significant Difference (LSD) test was performed to compare treatment means (Gelman, 2005). Pearson Correlation and Regression analysis were performed to know relationship among yield parameters and prediction of energy production.

\section{Results and discussion}

\section{Growth and yield performance}

Lettuce plant produced number of leaves in the range of 10-18 leaves per plant, leaves fresh weight (LFW) as 239-256 $\mathrm{g}$ and leaves dry weight (LDW) as 15-25 g. There was a significant influence of different concentrations $\left(\mathrm{T}_{\mathrm{o}}: 0 \%\right.$ GME and BPE (control), $\mathrm{T}_{1}: 1 \% \mathrm{GME}, \mathrm{T}_{2}: 2 \% \mathrm{GME}, \mathrm{T}_{3}: 3 \% \mathrm{GME}, \mathrm{T}_{4}: 3 \% \mathrm{GME}+1 \% \mathrm{BPE}, \mathrm{T}_{5}: 3 \%$ $\mathrm{GME}+2 \% \mathrm{BPE}$ ) of organic extract on number of leaves produced, LFW and LDW. The highest number of leaves per plant (18) was produced under $\mathrm{T}_{5}$ and reduced $(\mathrm{p}=$ $0.001)$ in $\mathrm{T}_{4}$ and rest of the treatments including control(Fig. 3A). The LFW (256 g) and LDW (25 g) of Lettuce were higher under $\mathrm{T}_{4}$ and $\mathrm{T}_{5}$ and reduced $(\mathrm{p}=0.001)$ in $\mathrm{T}_{3}, \mathrm{~T}_{2}$, $\mathrm{T}_{1}$, and $\mathrm{T}_{\mathrm{o}}$ (Fig. 3B,C). Compared to control, yield components of Lettuce were increased with increasing quantity of GME and BPE. Increased supply of extracts carried greater quantity of plant nutrients which have enhanced the yield components of Lettuce. The elements required in trace amounts are easily carried in organic extracts. The results are in agreement with Haggag et al. $(2014,2015)$ and where a manure compost tea was prepared and utilized for olive seedlings growth. Mowa et al. (2017) also noted increased growth and yield performance of tomato grown on goat manure.

\section{Moisture contents}

Leaf moisture of Lettuce was in the range of $90-94 \%$ and was influenced significantly due to concentration of organic extracts. It was reduced $(\mathrm{p}=0.001)$ in $\mathrm{T}_{1}$, $\mathrm{T}_{2}, \mathrm{~T}_{3}, \mathrm{~T}_{4}$, and $\mathrm{T}_{5}$ compared to $\mathrm{T}_{\mathrm{o}}$ (Fig. 3D). Under organic nutrition, moisture in Lettuce leaves was reduced and leaves became more hardy and crispy. Higher moisture in Lettuce leaves causes yellowing and reduces shelf life and market quality. 

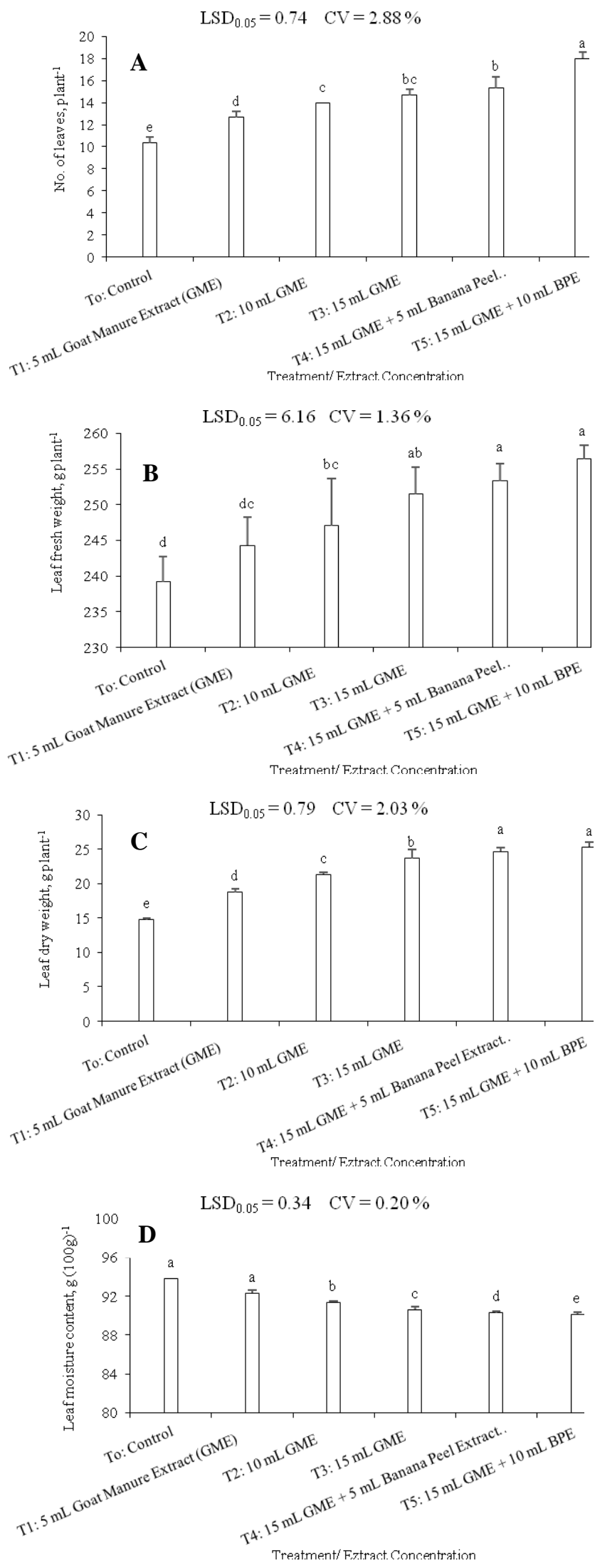

Figure 3. Effect of nutrient extracts of goat manure and banana peel extracts on number of leaves (A), leaf fresh weight (B), leaf dry weight $(C)$ and leaf moisture content $(D)$ of lettuce 


\section{Nutritional evaluation}

Protein, fat, carbohydrates, fibers, and ash contents in Lettuce leaves were in the range of 1.5-2.7, 0.3-0.7, 2.9-3.3, 0.7-1.4, and 0.5-1.5 g, respectively, and were varied significantly under different plant nutrition treatments (Table 2). The fat contents were increased $(\mathrm{p}=0.001)$ in $\mathrm{T}_{3}, \mathrm{~T}_{4}$ and $\mathrm{T}_{5}(0.8 \mathrm{~g})$ compared to that of $\mathrm{T}_{\mathrm{o}}, \mathrm{T}_{1}$ and $\mathrm{T}_{2}(0.3-0.6$ g). Leaf carbohydrates increased $(\mathrm{p}=0.001)$ under $\mathrm{T}_{5}$ compared to rest of the treatments including control. Leaf protein, fibers and ash contents were increased $(p=0.001)$ under $\mathrm{T}_{4}$ and $\mathrm{T}_{5}$ conditions compared to rest of the treatments.

Food nutrition of Lettuce leaves was enhanced under higher concentrations of GME and BPE owing to greater efficiency of organic culture carrying high nutritional value. Organic extracts have enhanced bioaccumulation of nutrients. This is in congruence with the findings of Bourn and Prescott (2002), Custic et al. (2003) and Uusiku et al. (2010) where greater nutritional value of organic foods was highlighted compared to conventional inorganic production.

Table 2. Effect of nutrient extracts of goat manure and banana peel on protein, fat, carbohydrates, fiber and ash contents of lettuce leaves

\begin{tabular}{l|c|c|c|c|c}
\hline \multicolumn{1}{c|}{ Extract concentration } & Protein, $\mathbf{g}$ & Fat, $\mathbf{g}$ & Carbohydrate, $\mathbf{g}$ & Fiber, $\mathbf{g}$ & Ash, $\mathbf{g}$ \\
\hline $\mathrm{T}_{\mathrm{o}}:$ Irrigation water $(0 \% \mathrm{GME} / \mathrm{BPE})$ & $1.5 \pm 0.2^{\mathrm{e}^{*}}$ & $0.3 \pm 0.0^{\mathrm{c}}$ & $2.9 \pm 0.1^{\mathrm{c}}$ & $0.7 \pm 0.1^{\mathrm{d}}$ & $0.5 \pm 0.1^{\mathrm{e}}$ \\
control & $1.8 \pm 0.1^{\mathrm{d}}$ & $0.4 \pm 0.1^{\mathrm{bc}}$ & $3.1 \pm 0.1^{\mathrm{ab}}$ & $1.0 \pm 0.2^{\mathrm{c}}$ & $1.0 \pm 0.1^{\mathrm{d}}$ \\
$\mathrm{T}_{1}: 1 \% \mathrm{GME}$ & $2.0 \pm 0.1^{\mathrm{c}}$ & $0.6 \pm 0.2^{\mathrm{b}}$ & $3.2 \pm 0.1^{\mathrm{ab}}$ & $1.2 \pm .01^{\mathrm{b}}$ & $1.3 \pm 0.1^{\mathrm{c}}$ \\
$\mathrm{T}_{2}: 2 \% \mathrm{GME}$ & $2.5 \pm 0.1^{\mathrm{b}}$ & $0.8 \pm 0.1^{\mathrm{a}}$ & $3.2 \pm 0.1^{\mathrm{ab}}$ & $1.3 \pm 0.1^{\mathrm{ab}}$ & $1.4 \pm 0.1^{\mathrm{bc}}$ \\
$\mathrm{T}_{3}: 3 \% \mathrm{GME}$ & $2.7 \pm 0.1^{\mathrm{a}}$ & $0.8 \pm 0.1^{\mathrm{a}}$ & $3.1 \pm 0.1^{\mathrm{bc}}$ & $1.4 \pm 0.1^{\mathrm{ab}}$ & $1.5 \pm 0.0^{\mathrm{a}}$ \\
$\mathrm{T}_{4}: 3 \% \mathrm{GME}+1 \% \mathrm{BPE}$ & $2.7 \pm 0.1^{\mathrm{a}}$ & $0.8 \pm 0.1^{\mathrm{a}}$ & $3.3 \pm 0.1^{\mathrm{a}}$ & $1.4 \pm 0.1^{\mathrm{a}}$ & $1.5 \pm 0.1^{\mathrm{ab}}$ \\
$\mathrm{T}_{5}: 3 \% \mathrm{GME}+2 \% \mathrm{BPE}$ & 0.16 & 0.14 & 0.17 & 0.17 & 0.11 \\
$\mathrm{LSD}(\mathrm{p} \leq 0.05)$ & &
\end{tabular}

*Different lower-case superscript letters with the column indicate significant difference between the mean values at $\mathrm{p} \leq 0.05$

\section{Mineral composition}

Calcium, phosphorus, sodium, potassium, chromium, and iron in leaves of Lettuce were in the range of 42-45, 32-37, 4.3-4.7, 58.3-60.6, 0.003-0.004, and 0.83-1.7 mg $(100 \mathrm{~g})^{-1}$ on dry weight basis, respectively, and were significantly influenced under varied plant nutrient management conditions. Contents of all these minerals were higher $(\mathrm{p}=0.001)$ under $\mathrm{T}_{3}, \mathrm{~T}_{4}$ and $\mathrm{T}_{5}$ conditions compared to $\mathrm{T}_{\mathrm{o}}, \mathrm{T}_{1}$ and $\mathrm{T}_{2}$ treatments (Table 3). Compared to control, treatments of organic extracts increased the mineral contents in Lettuce leaves. This shows potential of Lettuce for the take up of minerals supplied by the organic extracts. This is in agreement with the findings of Olle and Williams (2012) where mineral contents were increased compared to soil or inorganic nutrient based cultures.

\section{Vitamins production}

Thiamin, riboflavin, niacin and ascorbic acid analyzed in Lettuce leaves were noted in the range of $0.04-0.1,0.12-0.50,0.4-0.7$, and $7.0-10.7 \mathrm{mg}(100 \mathrm{~g})^{-1}$ on dry weight basis, respectively (Table 4). Contents of all vitamins in leaves responded differently to treatment concentrations tested. Contents of thiamin and ascorbic acid were greater $(\mathrm{p}=0.001)$ under $\mathrm{T}_{4}$ 
and $\mathrm{T}_{5}$ compared to rest of treatment conditions. Riboflavin and niacin were higher $(\mathrm{p}=$ 0.001 ) under $T_{3}$ and $T_{4}$ treatments compared to rest treatment environments. Increase of vitamins in organically produced vegetables has also been reported by Matt et al. (2011).

Table 3. Effect of nutrient extracts of goat manure and banana peel extracts on calcium, phosphorus, sodium, potassium, chromium, and iron contents of Lettuce leaves on dry weight basis

\begin{tabular}{|c|c|c|c|c|c|c|}
\hline Extract concentration & $\begin{array}{c}\text { Calcium } \\
\mathrm{mg}(100 \mathrm{~g})^{-1}\end{array}$ & $\begin{array}{l}\text { Phosphorus } \\
\text { mg }(100 \mathrm{~g})^{-1}\end{array}$ & $\begin{array}{c}\text { Sodium } \\
\mathrm{mg}^{(100 g)^{-1}}\end{array}$ & $\begin{array}{l}\text { Potassium } \\
\text { mg }(100 \mathrm{~g})^{-1}\end{array}$ & $\begin{array}{l}\text { Chromium } \\
\text { mg }(100 g)^{-1}\end{array}$ & $\begin{array}{c}\text { Iron } \\
\text { mg }(100 \mathrm{~g})^{-1}\end{array}$ \\
\hline $\begin{array}{l}\mathrm{T}_{\mathrm{o}} \text { : Irrigation water }(0 \% \\
\mathrm{GME} / \mathrm{BPE}) \text { control }\end{array}$ & $2.7 \pm 1.5^{\mathrm{b} *}$ & $32.0 \pm 1.0^{\mathrm{d}}$ & $4.3 \pm 0.1^{\mathrm{c}}$ & $58.3 \pm 0.1^{\mathrm{d}}$ & $0.003 \pm 0.001^{\mathrm{bc}}$ & $0.8 \pm 0.2^{\mathrm{d}}$ \\
\hline $\mathrm{T}_{1}: 1 \% \mathrm{GME}$ & $42.0 \pm 1.0^{\mathrm{b}}$ & $34.3 \pm 0.6^{\mathrm{a}}$ & $4.5 \pm 0.1^{\mathrm{ac}}$ & $60.0 \pm 0.2^{\mathrm{c}}$ & $0.003 \pm 0.001^{\mathrm{bc}}$ & $1.3 \pm 0.1^{\mathrm{c}}$ \\
\hline $\mathrm{T}_{2}: 2 \% \mathrm{GME}$ & $43.0 \pm 1.0^{\mathrm{b}}$ & $35.3 \pm 0.6^{b c}$ & $4.6 \pm 0.1^{\mathrm{ab}}$ & $60.3 \pm 0.1^{\mathrm{b}}$ & $0.003 \pm 0.001^{\mathrm{ab}}$ & $1.4 \pm 0.1^{\mathrm{bc}}$ \\
\hline $\mathrm{T}_{3}: 3 \% \mathrm{GME}$ & $45.0 \pm 1.0^{\mathrm{a}}$ & $36.0 \pm 1.0^{\mathrm{ab}}$ & $4.6 \pm 0.1^{\mathrm{a}}$ & $60.5 \pm 0.1^{\mathrm{ab}}$ & $0.004 \pm 0.001^{\mathrm{ab}}$ & $1.5 \pm 0.1^{\mathrm{ab}}$ \\
\hline $\mathrm{T}_{4}: 3 \% \mathrm{GME}+1 \% \mathrm{BPE}$ & $45.3 \pm 0.6^{\mathrm{a}}$ & $35.0 \pm 1.0^{\mathrm{bc}}$ & $4.7 \pm 0.1^{\mathrm{a}}$ & $60.6 \pm 0.1^{\mathrm{a}}$ & $0.004 \pm 0.001^{\mathrm{a}}$ & $1.7 \pm 0.1^{\mathrm{a}}$ \\
\hline $\mathrm{T}_{5}: 3 \% \mathrm{GME}+2 \% \mathrm{BPE}$ & $45.3 \pm 0.6^{\mathrm{a}}$ & $36.7 \pm 0.6^{\mathrm{a}}$ & $4.7 \pm 0.1^{\mathrm{a}}$ & $60.5 \pm 0.2^{\mathrm{a}}$ & $0.004 \pm 0.001^{\mathrm{bc}}$ & $1.7 \pm 0.1^{\mathrm{a}}$ \\
\hline $\operatorname{LSD}(p \leq 0.05)$ & 1.98 & 1.47 & 0.16 & 0.20 & 0.001 & 0.18 \\
\hline
\end{tabular}

*Different lower-case superscript letters indicate significant difference between the mean values at $p \leq$ 0.05

Table 4. Effect of nutrient extracts of goat manure and banana peel on thiamine, riboflavin, niacin, ascorbic acid and energy contents of lettuce leaves on dry weight basis

\begin{tabular}{|c|c|c|c|c|c|}
\hline Extract concentration & $\begin{array}{l}\text { Thiamine } \\
\text { mg }(100 g)^{-1}\end{array}$ & $\begin{array}{l}\text { Riboflavin } \\
\text { mg }(100 g)^{-1}\end{array}$ & $\begin{array}{c}\text { Niacin } \\
\text { mg }(100 g)^{-1}\end{array}$ & $\begin{array}{l}\text { Ascorbic acid } \\
\text { mg }(100 g)^{-1}\end{array}$ & $\begin{array}{l}\text { Energy } \\
\text { calories }\end{array}$ \\
\hline $\begin{array}{l}\mathrm{T}_{\mathrm{o}} \text { : Irrigation water }(0 \% \\
\mathrm{GME} / \mathrm{BPE}) \text { control }\end{array}$ & $0.04 \pm 0.01^{\mathrm{e}^{*}}$ & $0.12 \pm 0.07^{\mathrm{c}}$ & $0.40 \pm 0.10^{\mathrm{b}}$ & $7.00 \pm 1.00^{\mathrm{c}}$ & $20.67 \pm 0.23^{d}$ \\
\hline $\mathrm{T}_{1}: 1 \% \mathrm{GME}$ & $0.07 \pm 0.01^{\mathrm{d}}$ & $0.27 \pm 0.06^{\mathrm{b}}$ & $0.50 \pm 0.10^{\mathrm{b}}$ & $7.33 \pm 0.57^{\mathrm{c}}$ & $24.27 \pm 0.90^{\mathrm{c}}$ \\
\hline $\mathrm{T}_{2}: 2 \% \mathrm{GME}$ & $0.07 \pm 0.01^{\mathrm{dc}}$ & $0.33 \pm 0.06^{\mathrm{b}}$ & $0.47 \pm 0.06^{\mathrm{b}}$ & $7.33 \pm 0.55^{\mathrm{c}}$ & $26.73 \pm 1.16^{\mathrm{c}}$ \\
\hline $\mathrm{T}_{3}: 3 \% \mathrm{GME}$ & $0.08 \pm 0.00^{\mathrm{bc}}$ & $0.37 \pm 0.06^{\mathrm{ab}}$ & $0.53 \pm 0.06^{\mathrm{ab}}$ & $8.65 \pm 0.56^{\mathrm{b}}$ & $30.50 \pm 1.28^{\mathrm{a}}$ \\
\hline $\mathrm{T}_{4}: 3 \% \mathrm{GME}+1 \% \mathrm{BPE}$ & $0.09 \pm 0.01^{\mathrm{ab}}$ & $0.47 \pm 0.06^{\mathrm{a}}$ & $0.67 \pm 0.06^{\mathrm{a}}$ & $9.66 \pm 0.55^{\mathrm{ab}}$ & $30.90 \pm 0.89^{\mathrm{a}}$ \\
\hline $\mathrm{T}_{5}: 3 \% \mathrm{GME}+2 \% \mathrm{BPE}$ & $0.10 \pm 0.01^{\mathrm{a}}$ & $0.33 \pm 0.06^{\mathrm{b}}$ & $0.67 \pm 0.06^{\mathrm{a}}$ & $10.67 \pm 0.54^{\mathrm{a}}$ & $31.43 \pm 0.67^{\mathrm{a}}$ \\
\hline $\operatorname{LSD}(p \leq 0.05)$ & 0.01 & 0.11 & 0.14 & 1.22 & 1.59 \\
\hline
\end{tabular}

*Different lower-case superscript letters indicate significant difference between the mean values at $p \leq$ 0.05

\section{Food energy production}

Sum of energy supplied by food items is the ultimate goal that keep human body healthy and active for day to day work. It is a good parameter for comparing and evaluating different food products as beneficial for human health. Total energy production of Lettuce leaves computed from its carbohydrates, protein and fats contents was in the range of 20.731.4 calories. Energy value was influenced due to different waste extract concentrations (Table 4) and was improved $(\mathrm{p}=0.001)$ under $\mathrm{T}_{4}$ and $\mathrm{T}_{5}$ treatments compared to $\mathrm{T}_{0}, \mathrm{~T}_{1}, \mathrm{~T}_{2}$ and $\mathrm{T}_{3}$ treatments. Food energy was strongly related with number of Lettuce plant leaves $\left(\mathrm{r}^{2}\right.$ $=0.89)$, LFW $\left(\mathrm{r}^{2}=0.82\right)$, LDW $\left(\mathrm{r}^{2}=0.98\right)$ and leaf moisture $\left(\mathrm{r}^{2}=-0.98\right)$ (Fig. 4). Regression analysis $\left(\mathrm{r}^{2}=0.98\right)$ showed that food energy in Lettuce leaves is predictable using number of leaves, LFW, LDW, and leaf moisture content (Eq. 1). The higher nutritional quality of Lettuce leaves makes it better source of food energy as also observed 
by Iyaka et al. (2014). Crude carbohydrates, protein and fat contents were quite high in the vegetable samples, thus serve as good source of digestible energy. Furthermore, high potassium, sodium and calcium contents make it good food especially for hypertensive patient as potassium decreases high blood pressure. The proximate and mineral analysis indicates that consumption of Lettuce along with cereals in sufficient quantity could contribute immensely towards attainment of human nutritional needs for normal body growth, development and sufficient protection against diseases caused by malnutrition.
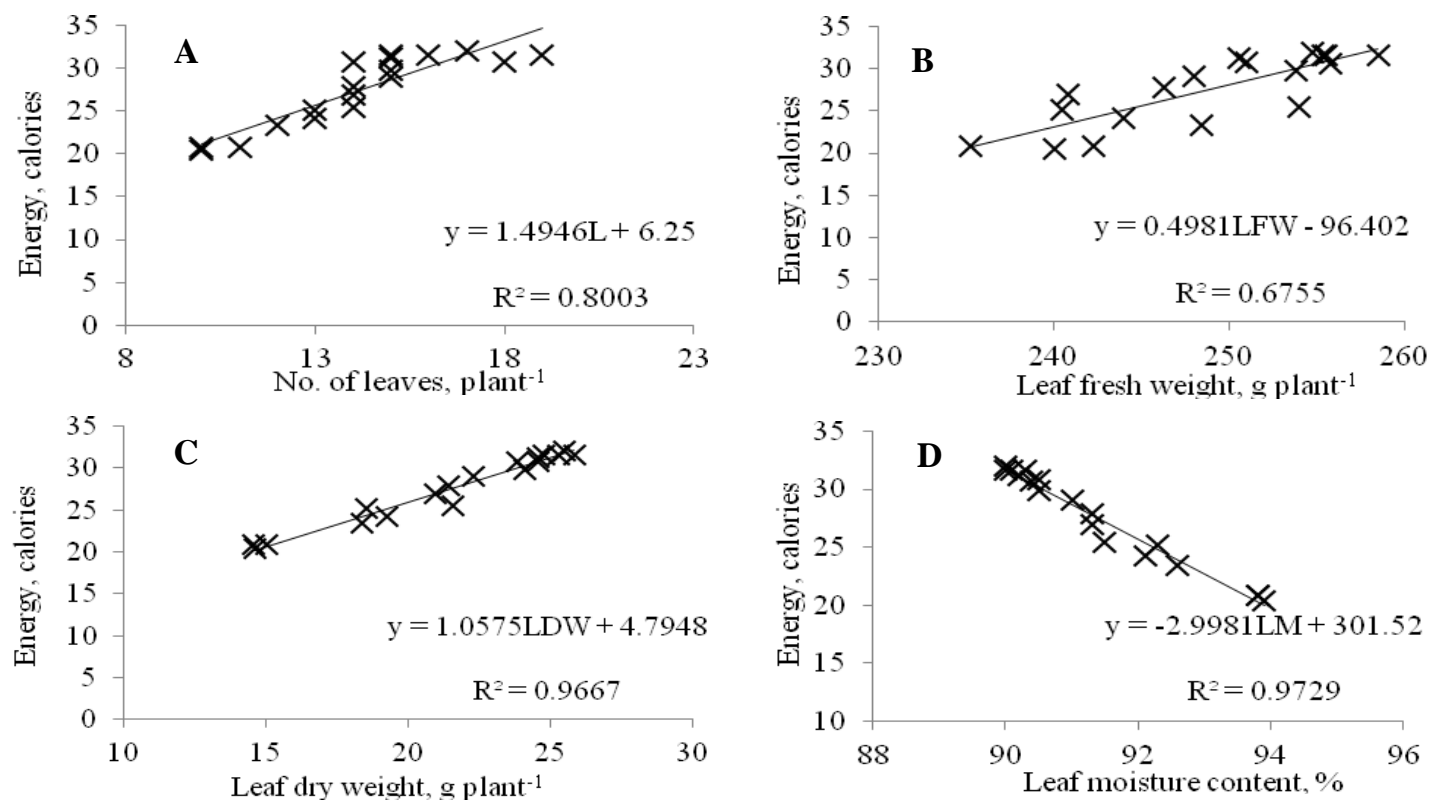

Figure 4. Relationship of energy contents with number of leaves (A), leaf fresh weight (B), leaf dry weight $(C)$ and leaf moisture content $(D)$ in lettuce

$$
\text { Engergy }(\text { Calories })=-563.5-0.132 L F W+4.016 L D W+6.55 L M
$$

\section{Conclusions}

The research results indicated the usefulness of organic extracts of goat manure and banana peel for hydroponic production of loose-leaf Lettuce in soilless mountainous and urban conditions. Lettuce grown under organic extracts had value added characteristics that can be marketed at higher prices. Bioaccumulation of food nutrients, minerals and vitamins in Lettuce leaves has been observed that encompass special significance for human nutrition and health benefits. Furthermore, this research suggests utilization of organic wastes especially goat manure and banana peel for the development sophisticated nutrient solutions for onward application in hydroponic systems. Soilless culture coupled with integrated use of evaluated organic waste extracts appears to be quite successful for gardeners and small farmers for intensive production of leafy vegetables or other high value crops for household use and income generation. It is strongly recommended for further research on use of goat manure and banana peel extracts for other leafy vegetables i.e., spinach, and also research studies on preparation and utilization of other animal and fruit wastes for the production of different leafy vegetables under hydroponic conditions. 
Acknowledgements. Financial support of Higher Education Commission (HEC) of Pakistan for this research through a research project SRGP: No. PD-IPFP/HRD/HEC/2013/1987 titled "Utilization of organic manures as potential source of nutrients for hydroponic vegetable production in Gilgit-Baltistan" is acknowledged. Services of Mr. Aqeel Ahmed, Mr. Umer Ahmad Farooq and Mr. Ibrar Anwar students of the Department of Agriculture \& Food Technology, KIU, during project execution are acknowledged.

\section{REFERENCES}

[1] Abbruzzini, T. F., Silva, C. A., Andrade, D. A., Carneiro, W. J. O. (2014): Influence of digestion methods on the recovery of iron, zinc, nickel, chromium, cadmium and lead contents in 11 organic residues. - R. Bras. Ci. Solo 38: 166-176.

[2] AOAC (Association of Official and Analytical Chemistry). (2000): Official methods of analysis, ed. W. Horwitz, $17^{\text {th }}$ ed. - AOAC, Gaithersburg, MD, USA.

[3] Arshad, M., Ranamukhaarachchi, S. L. (2012): Effects of legume type, planting pattern and time of establishment on growth and yield of sweet sorghum-legume intercropping. Australian Journal of Crop Science 6(8): 1265-1274.

[4] Bourn, D., Prescott, J. (2002): A comparison of the nutritional value, sensory qualities, and food safety of organically and conventionally produced foods. - Critical Reviews in Food Science and Nutrition 42: 1-34.

[5] Busuttil-Griffin, F., Shoemake, C., Attard, E., Azzopardi, L. M. (2015): Crude fibre determination of Malva sylvestris L. and evaluation of its faecal bulking and laxative properties in rats. - International Journal of Biology 7(4): 1-8.

[6] Clark, M. S., Horwath, W. R., Shennan, C., Scow, K. M. (1998): Changes in soil chemical properties resulting from organic and low-input farming practices. - Agronomy Journal 90: 662-671.

[7] Croft, M., Hallett, S., Marshall, M. (2017): Hydroponic production of vegetable Amaranth (Amaranthus cruentus) for improving nutritional security and economic viability in Kenya. - Renewable Agriculture and Food Systems 32(6): 1-10.

[8] Custic, M., Poljak, M., Coga, L., Cosic, T., Toth, N., Pecina, M. (2003): The influence of organic and mineral fertilization on nutrient status, nitrate accumulation, and yield of head chicory. - Plant, Soil and Environment 49: 218-222.

[9] Elamin, A. E., Elagib, M. A. (2001): Comparative study of organic and inorganic fertilizers on forage corn (Zea mays L.) grown on two soil types. - Qatar Univ. Sci. J. 21: 47-54.

[10] El-Kazzaz, K. A. and El-Kazzaz, A. A. (2017): Soilless Agriculture a New and Advanced Method for Agriculture Development: An Introduction. - Agri Res \& Tech: Open Access J. 3: 555610.

[11] Fabio, S., Vincenzo, D. B., Michele, P. (2007): Effects of N processing, fertilizers and rates on yield, safety and nutrients spinach genotypes. - Sci. Hortic. 114: 225-233.

[12] Fischer, W. R. (1986): Properties of and heavy metal complexation by aqueous humic extracts. - Journal of Plant Nutrition and Soil Science Banner 149(4): 399-410.

[13] Gelman, A. (2005): Analysis of variance-why it is more important than ever. - Ann. Statist. 33: 1-53.

[14] Golabi, M. H., Denney, M. J., Iyekar, C. (2004): Use of composted organic wastes as alternative to synthetic fertilizers for enhancing crop productivity and agricultural sustainability on the tropical island of Guam. - ISCO 200-13th International Soil Conservation Organisation Conference. Brisbane, July 2004 Conserving Soil and Water for Society. University of Guam, Mangilao, Guam, USA.

[15] Gonzalez, M. Q., Pellerin, A., Parent, E. P. (2016): Meta-analysis of lettuce (Lactuca sativa L.) response to added $\mathrm{N}$ in organic soils. - Canadian Journal of Plant Science 96(4): 670-676. 
[16] Haggag, L. F., Merwad, M. A., Shahin, M. F. M., Hoballah, E. M., Mahdy, H. A. (2014): Influence of mineral NPK and compost tea as soil applications on growth of "Aggizi" olive seedlings under greenhouse condition. - Middle East Journal of Agriculture Research 3: 701-706.

[17] Haggag, L. F., Shahin, M. F. M., Mahdy, H. A., Atteya, A. K. G., Hassan, H. S. A. (2015): Beneficial effect of NPK, pigeon manure tea and microbial fertilizers as soil application on growth of "Toffahi" and "Picual" olive seedlings. - Journal of Agricultural Technology 11: 1565-1582.

[18] Hucker, B., Wakeling, L., Vriesekoop, F. (2011): The quantitative analysis of thiamin and riboflavin and their respective vitamers in fermented alcoholic beverages. - Journal of Agricultural and Food Chemistry 59: 12278-12285.

[19] Iyaka, Y. A., Idris, S., Alawode, R. A., Bagudo, B. U. (2014): Nutrient content of selected edible leafy vegetables. - Amer. J. Applied Chem. 2: 42-45.

[20] Kawila, N. (2011): Studies of niacin and acrylamide during processing of instant Asian noodles. - PhD Thesis, School of Applied Sciences College of Science, Engineering and Health RMIT University, Melbourne, Australia.

[21] Khalil, I. A., Saleemullah. (2004): Chemistry One. Bio-analytical Chemistry. - T. S. Printers, Pakistan.

[22] Khattak, K. F., Rahman, T. U. (2016): Analysis of vegetable's peels as a natural source of vitamins and minerals. - International Food Research Journal 24(1): 292-297.

[23] Kittas, C., Katsoulas, N., Bartzanas, T., Bakker, S. (2013): Greenhouse Climate Control and Energy Use. (Chapter 4). - In: Good Agricultural Practices for Greenhouse Vegetable Crops-Principles for Mediterranean Climate Areas. - Plant Production and Protection Paper 217. Food and Agriculture Organization of the United Nations (FAO), Rome, pp 63-95.

[24] Kowalska, J., Niewiadomska, A., Głuchowska, K., Kaczmarek, D. (2017): Impact of fertilizers on soil properties in the case of Solanum tuberosum, L. during conversion to organic farming. - Applied Ecology and Environmental Research 15(4): 369-383.

[25] Manahan, S. E. (2005): Environmental Chemistry. 8th Edition. - CRC Press LLC, New York.

[26] Manolopoulou, E., Varzakas, T. (2016): Effect of temperature in color changes of green vegetables. - Curr Res Nutr Food Sci. 4 (Special Issue Conference October 2016).

[27] Masclaux-Daubresse, C., Daniel-Vedele, F., Dechorgnat, J., Chardon, F., Gaufichon, L., Suzuki, A. (2010): Nitrogen uptake, assimilation and remobilisation in plants: challenges for sustainable and productive agriculture. - Annals of Botany 105: 1141-1158.

[28] Matt, D., Rembialkowska, E., Luik, A., Peetsmann, E., Pehme, S. (2011): Quality of Organic vs. Conventional Food and Effects on Health. - Report. Estonian University of Life Sciences, Tartu.

[29] Mowa, E., Akundabweni, L., Chimwamurombe, P., Oku, E., Mupambwa, A. H. (2017): The influence of organic manure formulated from goat manure on growth and yield of tomato (Lycopersicum esculentum). - African Journal of Agricultural Research 12(41): 3061-3067.

[30] Olle, M., Williams, I. H. (2012): Organic Farming of Vegetables. - In: Lichtfouse, E. (ed.) Sustainable Agriculture Reviews. Vol. 11. Springer, Dordrecht.

[31] Orech, F. O., Christensen, D. L., Larsen, T. Friis, H., Aagaard-Hansen, J., Estambale, B. A. (2007): Mineral content of traditional leafy vegetables from western Kenya. International J. Food Sci. and Nutr. 58: 595-602.

[32] Orman, S., Kaplan, M. (2017): Agronomic biofortification of green bean (Phaselous vulgaris L.) with elemental sulphur and farmyard manure. - Applied Ecology and Environmental Research 15(4): 2061-2069.

[33] Raviv, M., Lieth, J. H. (2008): Soilless Culture: Theory and Practice. - Elsevier, London. 
[34] Rosik-Dulewska, C. Z., Grabda, M. (2002): Development and yield of vegetables cultivated on substrate heated by geothermal waters part 1: bell pepper, slicing cucumber, tomato. - J. Veg. Crop Prod. 8: 133-144.

[35] Roy, S. K., Chakrabarti, A. K. (2003): Vegetables of temperate climates: commercial and dietary importance. - Encyclopaedia Food Sci. Nutr. 5925-5932.

[36] Sgroi, F., Candela, M., Di Trapani, A. M., Foderà, M., Squatrito, R. (2015): Economic and financial comparison between organic and conventional farming in Sicilian lemon orchards. - Sustainability 7: 947-961.

[37] Smirnoff, N. (2000): Ascorbic acid: metabolism and functions of a multi-facetted molecule. - Curr. Opin. Plant Biol. 3: 229-235.

[38] Thiex, N. J., Anderson, S., Gildemeister, B. (2003): Crude fat, diethyl ester extraction, in feed, cereal grain, and forage (Randall/Soxtec/Submersion Method): Collaborative study. - J. AOAC Intl. 86: 888-898.

[39] Uusiku, N. P., Oelofse, A., Duodu, K. G., Bester, M. J., Faber, M. (2010): Nutritional value of leafy vegetables of sub-Saharan Africa and their potential contribution to human health: A review. - J. Food Comp. Anal. 23: 499-509.

\section{APPENDIX}

Supplementary Table 1. Simple statistical data

\begin{tabular}{|c|c|c|c|c|c|}
\hline Variable & $\begin{array}{c}\text { No. of } \\
\text { observations }\end{array}$ & Mean & $\begin{array}{l}\text { Standard } \\
\text { deviation }\end{array}$ & Minimum & Maximum \\
\hline No. of leaves, plant ${ }^{-1}$ & 18 & 14.17 & 2.48 & 10.00 & 19.00 \\
\hline Leaf fresh weight, g plant ${ }^{-1}$ & 18 & 248.61 & 6.83 & 235.30 & 258.50 \\
\hline Leaf dry weight, g plant ${ }^{-1}$ & 18 & 21.40 & 3.86 & 14.60 & 25.90 \\
\hline Leaf moisture, $\%$ & 18 & 91.42 & 1.36 & 90.00 & 93.90 \\
\hline Protein, $\mathrm{g}$ & 18 & 2.20 & 0.49 & 1.30 & 2.80 \\
\hline Fat, $\mathrm{g}$ & 18 & 0.60 & 0.20 & 0.30 & 0.80 \\
\hline Carbohydrates, $\mathrm{g}$ & 18 & 3.13 & 0.15 & 2.80 & 3.30 \\
\hline Fiber, g & 18 & 1.15 & 0.26 & 0.60 & 1.50 \\
\hline Ash, g & 18 & 1.20 & 0.36 & 0.40 & 1.50 \\
\hline Calcium, mg $(100)^{-1}$ & 18 & 43.89 & 1.64 & 41.00 & 46.00 \\
\hline Phosphorus, mg $(100)^{-1}$ & 18 & 34.89 & 1.68 & 31.00 & 37.00 \\
\hline Sodium, mg $(100)^{-1}$ & 18 & 4.56 & 0.16 & 4.20 & 4.80 \\
\hline Potassium, mg $(100)^{-1}$ & 18 & 60.07 & 0.85 & 58.20 & 60.80 \\
\hline Chromium, mg $(100)^{-1}$ & 18 & 0.00 & 0.00 & 0.00 & 0.01 \\
\hline Iron, $\mathrm{mg}(100)^{-1}$ & 18 & 1.41 & 0.31 & 0.70 & 1.80 \\
\hline Thiamine, $\mathrm{mg}(100)^{-1}$ & 18 & 0.07 & 0.02 & 0.03 & 0.10 \\
\hline Riboflavin, mg $(100)^{-1}$ & 18 & 0.31 & 0.12 & 0.07 & 0.50 \\
\hline Niacin, mg $(100)^{-1}$ & 18 & 0.54 & 0.12 & 0.30 & 0.70 \\
\hline Ascorbic acid, mg $(100)^{-1}$ & 18 & 8.44 & 1.50 & 6.00 & 11.00 \\
\hline Energy, calories & 18 & 27.42 & 4.14 & 20.40 & 32.00 \\
\hline
\end{tabular}

